NBER WORKING PAPER SERIES

\title{
REFORMS IN EASTERN EUROPE AND \\ THE FORMER SOVIET UNION IN LIGHT \\ OF THE EAST ASIAN EXPERIENCES
}

Jeffrey D. Sachs

Working Paper 5404

\author{
NATIONAL BUREAU OF ECONOMIC RESEARCH \\ 1050 Massachusetts Avenue \\ Cambridge, MA 02138 \\ January 1996
}

Prepared for the NBER-TCER-CEPR Conference on Transition from Socialist Economies, January 6-7, 1995, Tokyo. This research is part of an ongoing project with Professor Wing Thye Woo, University of California at Davis, on the comparison of economic reforms in Eastern Europe and East Asia. Forthcoming in Journal of the Japanese and International Economies. This paper is part of NBER's research programs in Economic Fluctuations, and International Finance and Macroeconomics. Any opinions expressed are those of the author and not those of the National Bureau of Economic Research.

() 1996 by Jeffrey D. Sachs. All rights reserved. Short sections of text, not to exceed two paragraphs, may be quoted without explicit permission provided that full credit, including $($ ) notice, is given to the source. 


\title{
REFORMS IN EASTERN EUROPE AND THE FORMER SOVIET UNION IN LIGHT OF THE EAST ASIAN EXPERIENCES
}

\begin{abstract}
During the past five years, there has been an important debate over the differing styles of market reforms in the formerly planned economies in East Asia versus Eastern Europe and the former Soviet Union (EEFSU). This paper puts forward three related propositions. First, the rapid growth of East Asia, compared with economic contraction in EEFSU, reflects differences in economic structure and initial conditions, rather than differences in economic policymaking. Second, East Asian gradualism could not, and did not, work in EEFSU. Third, EEFSU continues to face serious problems with an overextended welfare state inherited from the socialist period.
\end{abstract}

Jeffrey D. Sachs

Harvard Institute for International Development

One Eliot Street

Cambridge, MA 02138

and NBER 
Reforms in Eastern Europe and the Former Soviet Union in Light of the East Asian Experience

During the past five years, there has been an important international debate over the style of market reforms in the former centrally planned economies of East Asia, Eastern Europe, and the former Soviet Union. The economic performance across regions, summarized in Table 1, could not be more disparate, with rapid economic growth and low inflation in the East Asia transition economies of China and Vietnam, compared with sharp declines in GDP and high inflation in Eastern Europe and the Former Soviet Union (hereafter combined as EEFSU). This disparity has given rise to a plethora of theories about the underlying differences in the two regions, ranging over cultural, political, and economic factors.

At least three interpretations seem to have won widespread support. The first is that "gradual" economic reforms in East Asia have outperformed "shock therapy" economic reforms in EEFSU. The second is that Asian reformers put economic reforms ahead of political reforms, with superior economic results. In this view, 
premature democratization is seen to be a serious hindrance to EEFSU's economic performance. The third, raised by some Japanese analysts, is that EEFSU has unwisely rejected industrial policies that proved crucial for Japan's own post-war economic recovery. Such views have been influential not only in academic debate, but among policymakers in the transition economies and the donor community. For this reason, they deserve the most careful scrutiny.

In this brief survey paper, I seek to question these popular conceptions. I will put forward three related propositions concerning the differences in economic performance and economic policy across the two regions. The first proposition is that the differences in economic performance in the two regions are mainly the result of differences in economic structure and initial conditions rather than of differences in economic policymaking. ${ }^{1}$ The more rapid growth of East Asia's transition economies reflects mainly the fact that the East Asian economies began the reform process as highly agricultural and rural economies, with underdeveloped industrial sectors. The EEFSU economies, on the other hand, were heavily industrialized -- indeed overindustrialized -- economies, with most of the population in urban areas. These differences have profound consequences for 
growth rates, patterns of industrial development, income distribution, and political economy.

The second proposition is that East Asian gradualism could not succeed under the very different structural conditions of the EEFSU economies. This can be argued on theoretical grounds, once the nature of East Asian gradualism is properly understood. But it can also be demonstrated historically. During the second half of the 1980s, the Soviet Union and several of the Eastern European countries actually attempted Chinese-style gradualism, but the result was rising macroeconomic instability rather than increased economic growth. During the 1990s, several of the economies of the former Soviet Union continued to choose a "gradual" path, while a few countries of Eastern Europe choose a more radical course. After several years of experience, it is now possible to show that the more radical reformers have in fact had superior economic performance.

I will also stress two sub-themes related to the choice of economic policy in the EEFSU. The first is that Russia's extremely unstable macroeconomy during 1992-94 should not be attributed to a policy of "shock therapy," but rather to the failure of the Russian Government to pursue any sustained policy of macroeconomic control. As President Yeltsin himself wrote in 1994 (Yeltsin, 1994, p. 147), 
concerning Russia's long history of attempted reforms, "Russia's trouble was never a shortage or an abundance of reformers. The trouble was an inability to adhere to a consistent policy." The second sub-theme is that Japan's postwar "production priority system" was not an appropriate model for EEFSU policies after the collapse of communism, despite the suggestions of Teranishi (1994) and others. Japan's postwar conditions were completely distinct in structural terms from those found in the EEFSU in the 1990s.

The third proposition is that Eastern Europe continues to face serious problems as the result of an over-extended welfare state inherited from the socialist period. While the East Asian reforms are often viewed as "kinder and gentler" than the Eastern European and Russian reforms, the fact is that the social welfare state in the EEFSU, even after "shock therapy," is vastly more extensive than in East Asia. In fact, social spending as a percent of GDP has risen sharply in most countries of the EEFSU during the 1990s. The high and rising levels of social spending pose particularly difficult political and economic challenges for the Eastern European economies. The East Asian transition economies, by contrast, do not have such vast social welfare systems. In fact, the vast majority of the populations in China, Vietnam, Laos and other Asian transition economies, lack even rudimentary social 
support .

The paper proceeds as follows. Section II highlights some of the key differences in economic structure between EEFSU and East Asian economies. Section III shows how the structural differences affect the choice of economic strategies, and in particular, why gradualism was inappropriate in the EEFSU. Section IV considers the lessons of postwar Japan for reforms in the EEFSU. Section IV discusses some of the continuing difficulties in EEFSU caused by the legacy of an over-extended social welfare state. Section $V$ offers some conclusions.

II

In this section we make a three-way comparison of economic structure, involving EEFSU, the East Asian reforming economies, and Japan immediately after World War II. We argue that these three economies differ in several fundamental ways that go far to explaining their differences in economic performance, political dynamics, and policy needs. Therefore, this section provides the vital inputs for the analysis throughout the remainder of the paper.

The critical differences in economic structure revolve around 
the level of economic development. Eastern Europe and the former Soviet Union were much more industrialized and urbanized at the start of their reforms than the East Asian transition economies at the start of their reforms, or than Japan in the immediate postwar period (the second half of the 1940s). At the start of the reform period, and still today, the vast bulk of the EEFSU labor force is in industry and services, while in East Asia, the predominant proportion of the labor force is still in agriculture, reflecting a lower overall level of economic development. These differences have many ramifications for economic performance and policymaking. In the most general terms, they have made the transition to the market much more difficult in EEFSU than in East Asia.

The key differences in economic structure are evident in Table 2, which shows an estimated per capita GDP (adjusted for purchasing power parity, PPP); the sectoral structure of the labor force; and the proportion of the population in urban areas. We see that as of the early 1990s, China is still much poorer, agricultural, and rural, than Russia or the countries in Eastern Europe. Vietnam and Laos are even poorer, less industrial, and more rural than China. Notice that these differences are true even after fifteen years of market reform and rapid industrial growth in China. Thus, if we were to compare China in 1978, at the start of its reforms, with 
EEFSU at the beginning of post-communist reforms, the differences would be even more striking than in the table.

Notice also that Japan in 1950 was a relatively poor and rural society, with nearly one half $(48.3$ percent) of the labor force in the primary sector. While it is difficult to obtain a reliable comparison of income levels of Japan in 1950 with Russia and Eastern Europe today, the Summers-Heston income data put Japan's 1950 per capita PPP income at 9.8 percent of its 1990 level. This suggests an estimate of $\$ 1,900$ for 1950 , as shown in Table $2 .{ }^{1}$ This puts Japan's per capita income level in 1950 much closer to China's than to EEFSU's per capita income levels of 1991.

The differences in the sectoral allocation of the labor force in EEFSU and East Asia and in the social welfare systems were also reflected in the differences in the social organization of work under the respective socialist systems. In China, only 18 percent of the labor force as of 1978 were employed in state-owned enterprises, and only 8 percent were employed in state-owned enterprises in the industrial sector. Around 70 percent of the population were in agricultural communes (peasant villages), which

${ }^{1}$ We take Japan's GDP per capita in 1991 to be $\$ 19,390$ (UN Human Development Report 1994). Per capita GDP growth between 1990 and 1991 was 3.4 percent. Assuming that $\mathrm{GDP}_{1950}=0.098$ $\mathrm{GDP}_{1990,}$ we arrive at the estimate in Table 2 . 
were soon to be dismantled. This meant that by the early 1980s, only around one-fifth of the Chinese population worked in a state bureaucratic unit, while the rest of the population was employed outside of the state bureaucracy, as seen in Table 3. The vast majority of the population worked in activities that had almost no direct financial connection with the state. Peasant farmers did not receive social welfare transfers, state loans, or other kinds of direct state subsidies for production.

In the Soviet Union, by contrast, around 99 percent of the labor force in 1985 worked in state-owned enterprises of various sorts. The entire population, that is, was employed in work units that had a direct financial dependence on the state in one form or another. Even the collective farms (kolkhoz), for example, which constituted six percent of the labor force in 1985, were really state-owned bureaucratic units, which depended on the state for loans, subsidies, and allocations of physical inputs. Collective farm workers enjoyed guaranteed employment and income levels, protected by state subsidies. The same pattern of nearly 100 percent employment in state-owned enterprises was the rule throughout the EEFSU economies, with a partial exception for Poland, in which around 15 percent of the labor force was independent, peasant farmers. Even the Polish peasant farmers, 
however, received substantial state subsidies and depended on the state for inputs and for the sale of outputs.

Many studies have stressed that EEFSU was not only highly industrialized, but was in fact over-industrialized at the start of its reforms. Central planners had planned for a purpose: to create a vast military-industrial complex. The result was that the Soviet Union and the Eastern European communist countries succeeded in producing vast amounts of steel, coal, chemicals, and heavy machinery, to the neglect of consumer goods and services. As just one well-known example, in 1988 the Soviet Union produced 17 times more steel per dollar of GDP than did the United States (with GDP measured in PPP terms).

The EEFSU heavy industry was developed on the basis of very large inputs of energy per unit of output, with the energy resources supplied mainly by the Soviet Union. Enterprises both within the Soviet Union and within Eastern Europe received the energy at very low accounting prices, and the levels of energy consumption per dollar of GDP were several times higher than in the market economies or the East Asian transition economies. These sources of cheap energy came to an end at the start of the 1990s. Soviet oil and gas production began to fall precipitously at the end of the 1980s, forcing a rationing of energy resources within 
the Soviet Union. At the same time, the Soviet Union began to demand world prices for its energy exports to the central and Eastern Europe, thereby forcing a wrenching reduction in energy use throughout the region.

The main implications of EEFSU's higher level of economic development is that the socialist organization of the economy was far more deeply rooted in the EEFSU than in East Asia. For several reasons, it was possible to eliminate the communal organization of peasant agriculture in China within a matter of two or three years (1978-1980), and to revert to a household-based agricultural system. From the point of view of technology, it was easy and desirable to move from a communal organization of production to household production, which was the tradition in China for millennia. Production on the communes was extraordinarily labor intensive, with almost no shared machinery. From a political point of view, the peasants strongly supported decommunisation, since the communes were implicit taxpayers, through low state procurement prices for output, rather than recipients of state subsidies.

The single reform of changing from communal agriculture to household farms almost instantly freed around seventy percent of the Chinese labor force from socialist controls, thereby creating a dynamic pool of workers that provided the labor force for the 
new, non-state economy after 1978. On the other hand, china was not able in the course of fifteen years to make major changes in the socialist organization of the state industrial sector.

In the EEFSU, by contrast, there was no peasant sector that could be instantly liberated by a single agricultural reform. Not only was the agricultural labor force generally less than twentyfive percent of the total labor force, but the socialist organization of the large-scale, highly mechanized state farms were much harder to change than the labor-intensive, peasant farms of East Asia. It is not easy to convert very land-intensive and capital-intensive state farms into family farms, partly because it is difficult to allocate the extensive capital stock of the state farms. Moreover, the EEFSU state farms were generally large net recipients of subsidies from the budget and state financial institutions, so that farmers strongly resisted any attempts to cut the fiscal linkages with the state. Whereas Chinese peasants struggled to end the commune system, the EEFSU farmers generally struggled to preserve the flow of subsidies. Both by virtue of the modest size of the agricultural population in the EEFSU, and the political economy of the state farms, there was no way to "liberate" a large proportion of the EEFSU population from socialist control without a radical change in the organization of 
the state-owned industrial sector. This is the basic reason why some form of "shock therapy" proved to be necessary in EEFSU but not in East Asia.

Many other writers have also suggested that socialist organization sat more lightly on China than on EEFSU, on three related political economy grounds. First, Chinese central planning was far more decentralized regionally than was the case in the Soviet Union ( $\mathrm{Xu}$ and Qian). Second, the coverage of the plan was far less detailed as well, reflecting the much simpler and lessdifferentiated structure of the Chinese economy. This is reflected, for example, in the number of items under planning control: tens of thousands in China, millions in the former soviet Union (Xu and Qian). Third, the Cultural Revolution of 1966-76 in China broke the back of the centrally planning apparatus. Decentralized production outside of the plan had already started to emerge spontaneously in the first half of the 1970s, for example in the form of non-state township and village enterprises in the industrial sector. Moreover, the central bureaucracy was crushed by the Cultural Revolution, and thus was able to offer little resistance to the onset of market reforms (Sachs and Woo). 
In this section, we explore the links between economic structure and economic policy making. It will be useful to have in mind a radically simplified three-sector model of the economy as a backdrop for our empirical analysis.

We let sector 1 be peasant agriculture. We assume that sector 1 has very low productivity, based on a very simple technological structure of household-scale farming. Sector 2 is state-owned industry and services. It has a medium level of productivity, based on a fairly complex division of labor determined by the central planners. Workers are employed in large, urban-based, bureaucratic units. Sector 3 is privately-owned industry and services. It has a high level of productivity, based on a complex division of labor supported by market institutions. Sector 3 is initially prohibited, but is allowed to develop upon the start of market reforms.

In the pre-reform period, sector 1 is taxed (mainly through low agricultural prices set by a state purchasing monopoly). Sector 2, the state-owned sector, is subsidized in many explicit and implicit ways. The explicit subsidies appear in the budget. The implicit subsidies come through loans from the state banks; low food prices for urban industrial workers; preferential access to imports and foreign exchange; cheap energy; and so forth. Part of 
these subsidies are paid for through price controls on agriculture; part through explicit taxation; part through rationing of non-state enterprises; and part through inflation taxation, as a by-product of budget deficits and loans from the state banking sector. Sector 3 is initially prohibited. Even after the prohibition is removed, however, it tends to be taxed relative to the state sector, through explicit taxation, lack of access to needed inputs, and inflation taxation.

Dynamic economic growth after the start of market reforms depends on the rapid development of the high-productivity private sector. Socialist economies can achieve a moderate level of development based on the shift of workers from low-productivity peasant agriculture to moderately productive state-owned industry and services, but these economies then get trapped by the relative inefficiency of the state-owned sector compared with the marketbased privately-owned economy. The Soviet Union enjoyed some periods of fairly rapid growth up to the 1970s based on the transfer of workers from peasant agriculture to state-owned industry, but then stagnation set in during the 1970s and 1980s. As we noted in the previous section, the East Asian socialist economies had not progressed very far with the transfer of peasants to the state-owned industry and services by the time that they 
started their market reforms (China in 1978, Vietnam in 1986).

Within this simple framework, we can introduce two types of policies. The first, which we call "gradualism," is the end of prohibitions against sector 3, without significant changes in the subsidization of the state sector. More accurately, such a change is better called a "two-track approach," in which the state-owned (and non-peasant) sector is subsidized and protected, while the non-state sector is liberalized. Privatization, subsidy cuts, and bankruptcy of state enterprises are all introduced gradually if at all. The second policy is "shock therapy," in which most or all of the subsidies and protection directed at the state sector are removed at the same time that the non-state sector is liberalized. The essential difference in the two policies is not really the speed of reforms per se, since certain kinds of radical reforms were undertaken with blinding speed in "gradualist" East Asia (especially the dismantling of the commune sector in China during three years, 1978-81). The essential difference is that in EEFSU, the state enterprises are immediately subjected to market forces and a hard budget constraint, combined the expectation (not always realized) of quick privatization to follow. In East Asia, by contrast, the state enterprises are allowed to continue with a soft 
budget constraint and no clear expectation of eventual privatization.

Let us consider these alternative policies in our three-sector parable. Suppose, under a gradualist approach, that the previously prohibited sector 3 is now permitted. There is now the chance for high rates of economic growth based on the shift of workers to sector 3 from sectors 1 and 2 . Sector 1 workers (peasants) will almost surely choose to make the leap to sector 3 if they can find a job in the new sector, since wages in sector 3 will be higher than in sector 1 . Workers in state industry, on the other hand, may choose to remain where they are if the subsidies to sector 2 are larger than the difference in productivity between sectors 2 and 3. Thus, the inefficient state sector may survive even if it is less efficient than the private sector, if the subsidies to the state sector are large enough to compensate for the productivity difference. In East Asia, roughly 70 percent of the labor force was in sector 1 and only 15 percent in sector 2 at the start of market reforms. Thus, the flow of workers from sector 1 to sector 3 could proceed rapidly, even as state enterprise workers stayed on the highly subsidized jobs. In EEFSU, by contrast, perhaps 10 percent of the labor force, at most, was in sector 1, while 90 percent or more was in sector 2. As long as most of the workers 
remained in sector 2 , there could be no extensive flow of resources to the newly liberalized private sector. Successful reforms, measured by the creation of the highly productive private sector, would have to await the cut of state subsidies and the shrinkage of the state sector, through a combination of layoffs, quits following subsidy cuts, enterprise closures, and privatization.

Let us now turn to the actual experience under market reforms, first in East Asia, then in EEFSU. China's gradual, or two-track, approach began with the liberalization of the non-state sector starting in 1978. Liberalization of the Chinese non-state sector has meant three main things in practice: (1) the dramatic and rapid elimination of the commune-brigade system in agriculture, and its rapid replacement by the "household responsibility system" of individual household plots; (2) the freedom of local governments to establish township and village enterprises (TVEs) that operate outside of the central plan and on a market-basis for inputs and outputs; and (3) the opening of the Chinese economy to international trade and finance, especially in the Special Economic Zones (SEZs) in the coastal provinces. The rural reforms began in 1978-79 and the commune system was completely dismantled by 1981. The international opening of the economy began in the late 1970s, and has proceeded in stages during the past fifteen years. 
Chinese state enterprise reforms began in 1984 with a gradual increase in autonomy given to the state enterprises. But in the ensuing years, the enterprise reforms have remained gradual and limited. State enterprises have continued to receive subsidies for more than a decade; bankruptcy laws have barely begun to function; ownership transformation has been delayed; and the state workers continue to enjoy their iron rice bowl. It is estimated that even in the boom conditions of recent years, nearly two-thirds of state enterprises continue to lose money. Around half of the enterprises overtly lose money and are covered by budgetary subsidies; another fraction of enterprises covertly loses money, with the losses hidden in the form of subsidized state-bank loans and rollovers of bad credits.

The two-track approach in China indeed unleashed enormous growth in the non-state sector, including the TVEs and the coastal enterprises, while avoiding, at least until now, the political and social difficulties of closing loss-making state enterprises. Under the two-track approach, most state workers clung tightly to their subsidized jobs in the state sector, while peasant laborers have flowed to TVEs and coastal enterprises. As shown in Table 3 , the share of Chinese workers in state enterprises has actually been constant for fifteen years; all of the rise of the share of 
employment in the non-state industry has come from the decline of the share of agricultural employment. This contradicts the widespread idea that the Chinese state sector is "melting away" under the pressure of the reforms.

The Chinese two-track approach has been costly in fiscal and quasi-fiscal terms, with subsidies to loss-making state enterprises typically costing between 5 and 10 percent of GDP per year, both in direct budgetary outlays and in subsidized credits from the state banking system (see Sachs and Woo, 1994, for details). These subsidies have contributed to chronic inflationary pressures. Inflation reached nearly 30 percent per year in 1994, before falling to around 20 percent in 1995.

It is important to appreciate that market liberalization itself tends to exacerbate fiscal problems, even in the absence of explicit increases in budgetary subsidies to state enterprises. When state enterprises are given more autonomy during market reforms, they inevitably find ways to hide their incomes in the form of higher compensation for workers and management. This may come in greater expenditures for worker housing, or transport, or cafeterias in the factory, or simply higher take home pay. Moreover, with a legalized non-state sector operating alongside the state sector, state-enterprise managers discover ways to launder 
income through non-state enterprises that they establish as a conduit for skimming the state enterprise incomes. For both legal and illegal reasons, the state sector begins to report smaller profits or overt losses. Tax revenues decline and the budget deficit widens. This has occurred dramatically in China, with total government revenues as a percent of GDP falling from 34.8 in 1985 to just 18.4 in 1991 (Sachs and Woo, 1994, Table 9, p. 126). In this sense, market reforms -- whether two-track or shock therapy - introduce a race against time to protect the budget against growing losses in the state sector.

Even though China has so far avoided an extreme inflationary explosion, and even though the state sector is a relatively small employer, we should not overlook the risks of much greater inflation in China in future years as a result of the heavy subsidization of the state-owned sector. As Sachs and Woo (1994) explain, part of China's ability to control inflation has resulted from the rapid buildup of real money balances by the Chinese population. This buildup of real money balances has permitted high levels of seignorage without concomitant inflation. Between 1978 and 1992, M2/GDP rose from 32.3 percent to 96.1 percent (Gang Yi, 1994, Table 8.1, p. 111). We can surmise that the M2/GDP ratio will stop rising, particularly as households gain access to other 
stores of value in addition to savings deposits. In fact, the M2/GDP ratio has been roughly constant during the past two years. As a result of the stabilization of M2/GDP ratio, the inflationary consequences of a given rate of seignorage (as a percent of GDP) could be considerably worse than in the past. If, in turn, the higher inflation started to lead to declines in M2/GDP, and the dependence on seignorage persisted, it is possible that China could enter into a period of explosive inflation.

Vietnam offers a highly illuminating contrast to the Chinese experience (for recent accounts of Vietnam's reform experience, see Dapice, Haughton, and Perkins (1994), and Reidel and Comer (1995)). Vietnam began its market reforms in 1986, with the introduction of Doi Moi, meaning "reconstruction." These reforms were initiated partly in conjunction with Gorbachev's perestroika campaign in the Soviet Union. At the start of these reforms, Vietnam was even more agricultural and less industrial than China had been in 1978, with only 11 percent of the Vietnamese workforce in industry. The financial conditions were also far worse in Vietnam, partly as a result of extensive subsidies to consumers and enterprises, and partly as a result of expenditures on military operations. These financial conditions became even more grave in 1989, when the Soviet Union ended the traditional flow of cheap credits to 
Vietnam.

As a result of the financial exigencies, Vietnam launched a "shock therapy" market reform in March 1989, based on a decisive cut in subsidies, price decontrol, unification and floating of the currency in the foreign exchanges, liberalization of foreign trade, and the end of many prohibitions on private business. As in many EEFSU countries, these measures were introduced rapidly. The key difference between Vietnamese and EEFSU shock therapy was that Vietnam made no plans for the privatization of the state sector. This was hardly of decisive importance, however, given that state sector employment constituted a mere 15 percent of the labor force in 1989 (see Lindauer, 1994, Table 8.3). The results of the "shock therapy" were rapid and decisive. Inflation fell from 308 percent in 1988 to 74 percent in 1989 and 36 percent in 1990. GDP growth never slowed, rising by 8.0 percent in $1989,5.1$ percent in 1990 , and 6.0 percent in 1991 .

Vietnam's successful macroeconomic performance in the face of "shock therapy" makes clear that rapid East Asian growth has resulted not from "gradualism" instead of shock therapy, but from market liberalization in the context of a labor-intensive agricultural sector. As in China, Vietnam's non-state sector began to grow rapidly, as did labor-intensive exports, both from the 
state and non-state sectors. In the event, employment in the state sector fell very sharply (as occurred in EEFSU), by some 25-30 percent in 1989-90, but employment in this sector was such a small proportion of the overall labor force that GDP still grew very rapidly despite the sharp proportional decline in state-enterprise employment.

Could a gradualist approach -- defined as liberalization of the non-state sector combined with continued subsidization of the state sector -- worked in EEFSU? The answer is that it was in fact tried during the Gorbachev era, and it failed, for both structural and fiscal reasons. The communist reformers of the late 1980s fervently tried the two-track approach in EEFSU (see Berliner, 1993, and Sachs and Woo, 1994, for further details). Gorbachev's reforms paralleled the Chinese approach: a non-state sector, the so-called "cooperatives," were liberalized at the end of the 1980 s. At the same time, the state sector was given more autonomy, in enterprise reforms that were similar to those in China after 1984. The explicit and implicit subsidization of the state sector, however, was not eliminated. A similar combination of measures was undertaken in Poland in the second half of the 1980s, following the Gorbachev strategy.

In both the Soviet Union and Poland, the attempted gradual 
reforms failed, and for similar reasons. First, the non-state sector failed to grow dynamically. While there was a rise of employment and production in the non-state sector, it was not enough to compensate for adverse trends in the state sector. Nonstate firms remained hampered by their inability to attract labor and non-labor resources from the state sector, which still had the advantages of enormous subsidization. It is clear, for example, that the new Polish private sector began to grow dynamically only after radical reforms began in 1990, not during the phase of "gradual" reforms during 1987-89 (see Sachs, 1993, and Johnson and Loveman, 1995, for details).

Second, the increasing autonomy of the state sector, combined with the traditional soft-budget constraints of that sector, led to a rapid deterioration of the macroeconomy. Wages in the state enterprises soared, and tax collections from these enterprises plummeted, as had occured as well in China. In EEFSU, where the state sector was generally 90 percent or more of the labor force, rather than 10-20 percent as in East Asia, the cost of state-sector subsidies tended to rise far above 10 percent of GDP, and inflationary pressures were far worse as a result. Sharp cuts in state-enterprise subsidies were therefore vital to get inflationary pressures under control. Increasing macroeconomic instability, 
more than any other factor, was the proximate cause of "shock therapy" reforms (as was true in Vietnam as well).

After several years of reform experience in EEFSU, we now have a track record for comparing shock therapy versus gradualism within the EEFSU countries. While a few countries -- the Czech Republic, Estonia, Poland, Slovenia -- successfully implemented radical economic reforms, many others such as Romania and Ukraine, staunchly defended a gradualist course. Russia, unfortunately, followed no consistent policy. Several studies (most recently Balcerowicz and Gelb, 1994) have shown that it is the countries pursuing shock therapy that have best succeeded in restoring economic growth and broad macroeconomic stability, while the gradualists have tended to experience continuing declines in output and accelerating inflation. Both Ukraine and Russia announced at the end of 1994 their intention to proceed with more decisive stabilization measures in 1995.

Some evidence on this point is shown in Table 4, where we rank economies according to the intensity of their reforms using a simple index built upon classifications of transition reforms made by the European Bank for Reconstruction and Development (1994, Table 2.1, p. 10). The EBRD ranked the reforms of all of the transition economies of the EEFSU according to six criteria, on a 
scale from 1 (least reform) to 4 (most reform). We construct an overall index by taking the sum of these six components, and then rank countries on a scale from 4 to 24 . The six dimensions of reform are: large-scale privatization, small-scale privatization, enterprise restructuring, price liberalization and competition, trade and foreign exchange system, and banking sector.

We compare the overall reform index with two measures of aggregate performance: cumulative change in GDP during 1989-94, and the change in GDP during 1994. We show in Figures 1 (a) and $1(b)$ that more intensive reform is indeed associated with a smaller cumulative GDP decline during 1989-94, and with faster GDP growth in 1994. The strong reformers experienced an average GDP decline between 1989 and 1994 of 18 percent; the moderate reformers, a decline of 36 percent; and the weak reformers, a decline of 51 percent. Similarly, the strong reformers enjoyed 1994 GDP growth of 4 percent; the moderate reformers, -1 percent; and the weak reformers, -21 percent. The relationship between the intensity of reform and GDP growth (cumulative and 1994) is found to be statistically significant when the two growth variables are regressed on the reform index (RI), using the data of Table 4:

$$
\div \Delta \mathrm{GDP}_{89-94}=-78.0+2.68 * \mathrm{RI} \quad \mathrm{R}^{2}=0.392
$$




$$
(-7.3) \quad(3.86)
$$

$$
\because \Delta \mathrm{GDP}_{94}=\begin{aligned}
& -41.7 \\
& (-7.8)
\end{aligned}+\begin{gathered}
2.33 * \mathrm{RI} \\
(6.68)
\end{gathered} \quad \mathrm{R}^{2}=0.660
$$

(t-statistics in parentheses).

These equations are hardly a full model of post-communist growth in the EEFSU. Both the growth and the reform variables suffer from significant measurement error, and country-specific endowments (extent of industry, energy resources, geography, and so forth) play an important role in the short-run dynamics of growth. Nonetheless, these results support the view that stronger reform has been associated with a smaller drop of GDP and a quicker recovery of growth.

It is worth stressing that Russia is hardly an exemplar of "shock therapy" reforms, as evidenced by the Russia's value of 16 on the reform index in Table 4. While casual observers sometimes attribute the macroeconomic chaos in Russia during 1992-94 to the introduction of shock therapy reforms, it is more accurate to say that macroeconomic instability resulted from the absence of coherent macroeconomic policies during those years. During most of this period, the Russian Central Bank pursued a highly inflationary policy of cheap credits to state-owned industry, while conflicts 
between the Government and the Parliament contributed to sustained budget deficits on the order of 10 percent of GDP. Details on the inconsistencies of Russian macroeconomic policy are described in Sachs (1995).

Many analysts point to the downturn in GDP and in industrial production throughout the EEFSU as a prima facie evidence that "shock therapy" has failed in the region, at least compared with the two-track reforms in China. But as we have stressed, such an analysis confuses the results of structure with the results of economic policy. (This is especially true since the largest GDP declines were in the countries with the least intensive reforms). Rapid price liberalization and subsidy cuts caused a steep downturn in industrial production in Eastern Europe and the former Soviet Union mainly because those economies had an enormous excess of heavy industrial production relative to services and consumer industries at the start of reforms. Industries such as steel, coal, chemicals, and some machine building, faced a sharp fall in demand once the budget constraints of their customers (especially in the military sector) were hardened. The decline in such overproduction is crucial to enable the growth of new sectors, which is why the strong reformers actually ended up with the smallest cumulative decline between 1989 and 1994, and the fastest return to 
positive growth.

Another common criticism of shock therapy is that it led to sharp drops in living standards in EEFSU, as contrasted with unambiguous increases in living standards in East Asia. Official data have vastly exaggerated the purported declines in income in EEFSU after the start of market reforms, for several related reasons: private sector economic activity is systematically under reported; the increased availability and quality of consumer goods is not captured in the data; the welfare gains of reduced queuing time are also not measured. In the case of Poland, for example, the widespread assumptions of a sharp drop in living standards after 1989 has been completely refuted by a series of careful analyses. We now know that Poland's reforms in fact ushered in a boom in consumer durables purchases for virtually all social groups, combined with stable or even increasing levels of consumption of non-durables. Real consumption in most broad categories of the population has increased, not decreased sharply as was once assumed.

In China, by contrast, the visible boom in the urban areas has tended to mask continuing hardships in much of the countryside, and among the unregistered "floating population" in the cities (which now totals between 100 million and 200 million persons). Recent 
press accounts have depicted the harrowing conditions of young women who have come from the countryside to urban areas to work for bare subsistence wages under dangerous factory conditions. Official data show that the urban-rural inequality in China has widened sharply since 1985, so that the gap between urban and rural households is wider than at the start of the reforms in 1978. We simply do not have a solid picture as to the proportion of the Chinese population that might have suffered real income declines in recent years, especially in the underreported countryside.

Note that the East Asian two-track strategy would be a more convincing model for EEFSU if we could find evidence that China's gradual state enterprise reforms had in fact restored vitality to the state enterprise sector. Unfortunately, in this area of most importance for EEFSU, there is little sign of progress in the Chinese reforms, despite 10 years of effort at state enterprise reforms. We find that after 10 years, the Chinese state enterprises remain heavily loss making, with productivity levels and productivity growth that lag behind the non-state firms, and with evidence of growing corruption, asset stripping, and pressures for privatization. The best evidence is that China will eventually have to follow the Eastern European strategy of privatization in order to eliminate these chronic and unsolved problems. It has had 
the luxury to avoid this decision mainly because of the small relative size of the state-enterprise sector in total employment.

To summarize the empirical arguments to this point:

economic growth is rapid in the East Asian transition economies mainly because of the rapid shift of employment from lowproductivity agriculture to high-productivity non-state enterprises; (2) economic growth in EEFSU was initially negative after market reforms because market forces induced a decline in heavy industrial production as a prelude to economic growth in new, non-state enterprises; (3) the two-track approach in China could be successful because of the modest size of the state-owned enterprise sector at the start of market reforms; (4) "shock therapy" reforms in Vietnam did not lead to a measured decline in GDP because of the small size of the state industrial sector in Vietnam in 1989; gradualism was tried, and failed, in EEFSU: it was insufficient to spur the non-state sector, while it exacerbated macroeconomic instabilities in the state sector.

IV

A different, state-led approach for the EEFSU has been recommended by some Japanese economists based on the rapid recovery 
of the Japanese economy in the immediate postwar years (especially the late 1940s). Prof. J. Teranishi (1994) has pointed favorably to Japan's industrial policies during 1946-48 as the types of policy measures needed in EEFSU. Unfortunately, the conditions in Japan during that period were so fundamentally different from those of EEFSU or East Asia today that such analogies are highly misleading.

In the immediate aftermath of World War II, Japan suffered from an extreme collapse of industrial production, with overall industrial production on the order of 20 percent of the 1939 level. There were several factors leading to the sharp decline in industrial production between 1939 and 1945, including: extensive war damage to basic industries; (2) severe bottlenecks in scarce inputs, because of a complete control on Japanese trade by the U.S. Military Occupation authorities; (3) a crisis in domestic production caused by the sudden shortage of coal miners, as forced laborers from Korea and China left the coal mines at the end of World War II to return home; and (4) a shortage of capacity caused by the wartime conversion of some civilian industries to military use.

In these circumstances, the Japanese government was able to target a small number of basic industries in 1946-48 (mainly steel 
and coal) to overcome the production bottlenecks, in a policy known as the Priority Production System (Keisha Seisan Hoshiki, PPS). As summarized by Yoshikawa and Okazaki (in Teranishi and Kosai, 1993, p. 97):

The primary purpose of the policy was to input as much steel as possible in to the coal mines and then, in return, send coal back to the steel industry to make a kind of virtuous cycle between two industries. Because the Japanese economy faced at that time a serious shortage of raw materials, this policy was essentially an attempt to substitute domestic production of coal for interrupted imports, and made sense, at least in theory. How successful the policy actually was still remains a controversy today. (Emphasis mine)

Fukao, et. al. (1993, p. 112) concur that the PPS was "a desperate move by the Japanese government in response to SCAP-imposed constraints on the import of industrial materials." [note: SCAP is the Supreme Commander of the Allied Powers, i.e. the U.S. military occupation authority]. By 1947, U.S. restrictions on Japanese imports were relaxed, as the U.S. changed course and began to promote Japanese economic recovery as part of the emerging cold-war strategy. Industrial production increased sharply, and the main mechanisms of the PPS were dismantled by 1949 .

This description of the PPS shows how different is the current challenge faced by EEFSU. These countries do not face "supply bottlenecks" as in postwar Japan, but rather deep misallocations 
and waste of industrial resources. Unlike Japan in 1946, EEFSU faces no international constraints on its imports; no sudden shortfall of industrial employment; and no war damage. Moreover, EEFSU's aim is not to increase steel and coal production, simply because the basic capacity is present. The traditional heavy industries in EEFSU -- coal, steel, chemicals -- are in a crisis of overcapacity, not supply bottlenecks. The need is to cut back the heavy industrial output, to make room for light industry (e.g. food processing), consumer goods, and services.

There are certainly many relevant lessons from the Japanese postwar recovery, but they have little to do with industrial planning, and much more to do with the establishment of a competitive, privately owned economy. First, and perhaps most relevant, the Japanese economy was demilitarized after World War II. Japan became a civilian-oriented economy, with economic growth was fueled by consumer goods rather than heavy industry, and with security needs provided mainly by the U.S. security umbrella. Second, land reform after the war improved the distribution of income and wealth, and established a wide base of property holders. These factors were favorable for agricultural productivity and even more importantly for political stability. Third, competition was enhanced through the dissolution of the large industrial 
conglomerates (Zaibatsu). Later on, of course, new industrial groups (Keiretsu) emerged, but these new groups were less tightly integrated than the Zaibatsu had been. Fourth, Japanese labor markets were made highly competitive. Hiring and firing was left to the discretion of individual enterprises; unions were relatively weak; and labor legislation was also permissive. Fifth, the postwar Japanese boom was fueled by privately owned industrial enterprises rather than state-owned enterprises. Sixth, after 1949, the Japanese economy operated with a low budget deficit, low inflation, and a unified, stable nominal exchange rate. Fiscal stability was supported by low levels of social expenditures as a percent of GDP.

These key features of the postwar Japanese economy are virtually missing from Russia, which remains militarized, oligopolistic, hamstrung by extensive social welfare guarantees (if now much underfinanced), and with continued state ownership of most land and farms. Russian budget deficits remain on the order of 1015 percent of GDP, fueling inflation rates of more than 10 percent per month for most of the period 1992-94. When Russian analysts wax rhapsodic about Japanese postwar planning, they usually believe that the role of state could be carried out in lieu of these more fundamental changes. 
Suppose that the EEFSU countries are finally able to carry out the fundamental reforms of ownership, macroeconomic policy, and competition policy. Would they then be advised to pursue MITIstyle planning as an additional element of their strategy? of course, this question can not be simply answered. There is a huge disagreement about the real character of Japanese industrial policy; it has changed markedly over the years; and there is enormous professional disagreement about its effectiveness. The most recent research on the East Asian economies has landed in a split decision over whether industrial planning helped or hindered the overall development effort, with Rodrik (1995) suggesting important positive effects, while Young (1994) and Weinstein (1994) have argued against such effects.

But whatever the conceptual judgement on industrial policy, there is one practical factor that militates strongly against any extensive industrial policy at this stage. Throughout the region, the bureaucracies have been inherited from the communist era, and are generally deficient in the knowledge of basic market economics, much less conditions in the world economy. More over, these bureaucracies tend to be highly corrupt (a legacy of the communist past), and penetrated by key interest groups from agriculture and the military-industrial complex, that are much more interested in 
extracting rents or preserving old structures than they are in overhauling the economy. In short, they lack the technical knowledge, experience, training, and political insulation that was vital for effective planning in Japan and South Korea. Under any circumstances, it should be a high priority to create a new, professional civil service in the economics ministries, but that effort will take a decade at the very least.

There is one more factor in Japan's postwar experience that has been widely forgotten today. Japanese recovery, like Western European recovery, benefitted enormously from U.S. financial assistance at the end of the 1940s and the early 1950s. Japan received $\$ 980$ million in U.S. aid during 1946-48, and $\$ 1.2$ billion during 1949-52. Of the total $\$ 2.2$ billion, $\$ 1.7$ billion was in the form of grants rather than loans. During the 1946-48 period, the aid amounted to roughly 4.2 percent of GDP, and during the 1949-52 period, to roughly 2.3 percent of Japanese GDP. ${ }^{2}$

This aid was vital in giving the postwar governments sufficient resources to maintain domestic political stability while meeting urgent economic needs (see the discussion in Eichengreen and Uzan, 1992, for an analysis of the stabilizing effects of the Marshall Plan). It also gave the opportunity for policy conditionality in Japan, in the form of the Dodge Plan, which 
finally succeeded in stabilizing the Japanese economy. Despite the fact that the needed aid to Russia would constitute a minuscule fraction of Western GDP, the West consistently failed to support the Russian Government in the early stages of reform. ${ }^{3}$ Thus, all of Russia's intrinsic difficulties - - fiscal crisis, weakness of law, structural imbalances -- were given time to destabilize the economy, without being held in check by outside resources that could have come from donor governments. (See Sachs, 1995, for further details on the failures and inadequacies of the Western aid program for Russia since 1991).

Let us turn now to some additional aspects of the political economy of reform in the two regions. It is often asserted that China's gradualism has allowed a much more stable transition to the market than EEFSU's radical reforms. Many observers point to the considerable turmoil and dissatisfaction evident in EEFSU, in apparent contrast to the relatively smooth path of change in the East Asian economies. Moreover, it is asserted that premature democratization in EEFSU has further burdened the economic reforms. This line of analysis requires several responses. 
First, the countries of EEFSU are vastly freer in political debate than are the East Asian countries. For this reason alone, there is no easy way to calibrate the differing degrees of dissatisfaction and social instability. During a brief period of political liberalization in 1988-89, China experienced mass unrest, which was repressed by army in June 1989. Moreover, there has been extensive unrest in the Chinese countryside, especially in 1993 and 1994, but political suppression and the absence of uncensored media make it hard to calibrate.

It is clear that politicians in both EEFSU and East Asia have found it extremely difficult to reduce employment in over-manned state-owned enterprises. In China, there has been almost no retrenchment of labor in state enterprises during the past decade, despite many attempts at "enterprise reform." Recently, attempts to introduce new bankruptcy proceedings in loss-making state firms were met with civil unrest and strikes, prompting local Chinese officials to reverse the bankruptcy orders. The big difference between the regions, therefore, is not in the ability to undertake restructuring, but in the fact that EEFSU simply needs much more restructuring than East Asia, because EEFSU starts from a much higher level of industrialization, and a much greater degree of structural imbalance in the economy. 
Put another way, reforms in East Asia are more naturally pareto improving than comparable reforms in the EEFSU: the vast majority of the East Asian population stands to benefit, as lowincome peasants increasingly find opportunities for employment in non-state industry and services. In the EEFSU, by contrast, many state enterprise workers stand to lose at the outset of reforms. This will be true even if the winners will tend to outnumber the losers by a wide margin. We should also keep in mind that uncertainty related to structural adjustments can generate a majority political opposition to reform even when a majority of the population stands to benefit ex ante from the reforms (see Fernandez and Rodrik, 1991, for an important theoretical analysis of this point).

Perhaps the most difficult political aspect of economic reform in the EEFSU is that governments in the region are held accountable by their citizens for universal social welfare -- including state guarantees of employment, income, education, housing, health, and other services -- whereas in China, the social welfare system has never really extended beyond the urban areas.

State workers in China receive a so-called "iron rice bowl," signifying the guarantee of job tenure, adequate income, and other kinds of benefits (lodging, pensions, health care), but such 
guarantees apply to less than 20 percent of the labor force, and does not reach the rural sector. The vast majority of the Chinese peasantry, by contrast, wants little more from the government than to be left alone. Peasants have a natural (if rudimentary) safety net in the form of the household plot of land. Poor families can rely on their own agricultural output to achieve the bare minimum of subsistence. The EEFSU, by contrast, carries the burden of decades of ideological and programmatic commitments to universal social guarantees. The "iron rice bowl" in the EEFSU was nearly universal, at least in theory. Moreover, since most of the EEFSU population is urban, most households lack any guaranteed source of subsistence other than from the state itself.2

Perhaps as a result of their ideological competition with the much richer Western European countries on the their borders, promised their citizenry levels of social welfare payments and guarantees that were vastly out of line with the per capita income levels in EEFSU. These welfare guarantees not only contributed to the insolvency of the EEFSU governments, many of which are still in default on their international debt obligations, but have also

\footnotetext{
${ }^{2}$ Recent research has shown however an astoundingly high proportion of Russian and Ukrainian urban households that depend, at least in small part, on their own garden plots for part of their food supply.
} 
contributed to political paralysis in the EEFSU, by making every needed adjustment in the economy a violation of a preceding guarantee to some class of workers. The ambition of the social guarantees in the Soviet Union was especially remarkable, even by comparison with the social welfare arrangements of the OECD economies.

In an important recent work, The soviet social contract and Why it Failed, author Linda Cook (1993) characterizes in detail the all-embracing ambitions of the Soviet social welfare state during the Brezhnev era. She describes the "social contract" under the authoritarian Brezhnev regime, in which "the soviet regime consistently [should] deliver to workers economic security and social welfare," and "workers [should] give in exchange political compliance and quiescence." (p. 5). At the core of this system lay job security, which guaranteed not only employment but also protection against downgrading of the job:

A worker's right to his or her existing job was protected by labor legislation that sharply restricted managers' ability to fire or transfer workers, placed multiple procedural barriers to dismissal even for incompetence or disciplinary violations, and extended strong guarantees to marginal workers (including youth and women with young children). (p. 26)

In addition, the Brezhnev era promised substantial real wage 
increases, a narrowing of income inequalities across regions and sectors (including, inter alia, a commitment to close the gap between the urban and rural areas), and guarantees of "a long list of basic necessities and social services, including education, child care, medical care, housing, public utilities, public transport, stipends, disability payments, and lunch programs." (p. 21).

The enormous fiscal costs of the EEFSU social welfare system may be seen in Table 5, which shows measures of the fiscal burden of social welfare spending for different regions. Unfortunately, readily available, cross-regional data are a bit out of date, in this case applying to the years 1985-90. In fact, the large differences between EEFSU and East Asia seen in the table would loom even larger with more recent data, because of the steep increase in social spending in many EEFSU economies. We see in Table 5 that the burden of social expenditures in Eastern Europe was roughly on the level of the OECD economies, even though the average per capita income level was roughly one-fourth $(\$ 5,210$ compared with $\$ 19,000) !$ Both South Asia and East Asia have very small social security systems, 3.4 percent of GDP on average in East Asia, and only 0.7 percent of GDP in South Asia. Table 6 shows similar data on a cross-country basis, for various years 
1985-92, for one major category of social spending: pension benefits. Once again, we see that EEFSU is carrying a fiscal burden similar to that of the OECD, despite the much lower GDP per capita .

In the aftermath of World War II, Japan was far more like East Asia of today than EEFSU with regard to social welfare spending. In Table 7 , all social security payments made to individuals, by all levels of government, are added to arrive at a total "transfers" estimate, based on the important work of Emi (1978). Emi lists six subcategories of social security payments, including "livelihood protection, social welfare, social insurance, unemployment measures, measures for health care and sanitation, and pensions," to arrive at the total transfers. We see that as during 1946-50, total transfer payments amounted to just 2.2 percent of GDP, while pensions alone amounted to around one-tenth of one percent of GDP. During 1951-55, the transfer payments had increased to around 3.8 percent of GDP, which pensions still below one percent of GDP. Thus, as is well known, Japan lacked any extensive state social welfare system after World War II. Japanese governments called on the population to rely on personal effort, high savings, and intra-family transfers to address personal financial hardships. 
An enormous amount of political activity in Eastern Europe is now devoted to protecting the previous social welfare commitments. The return of left-wing parties to political power throughout Eastern Europe should be understood mainly as a result of the popular view among voters that these post-communist parties will better protect the "entitlements" that had been promised by the old regime. The most powerful block of left-wing voters seems to be the pensioners, who represent a surprisingly large proportion of the electorate and who lobby aggressively for increases in real pension payments. In Poland and Hungary, pensioners living off of the state now account for around one-third of all adults, and in Slovenia the proportion is closer to forty percent of the adult population! The result of these political pressures is clear: social spending has actually increased sharply in most countries of Eastern Europe in recent years, even as subsidies to state industry have been cut, as shown in Table 8 .

The heavy social spending in Eastern Europe is not only historically unprecedented for countries at this income level, but is clearly a major threat to macroeconomic stability, and perhaps as well to rapid and sustained economic growth. The high level of social spending is contributing to chronic budget deficits in many countries, as is the case in the OECD. Moreover, with the aging of 
the population in EEFSU, the fiscal burden is likely to rise significantly if there are no major changes cutbacks in the extent of pension benefits (see World Bank, 1994, Chapter 8, for further discussion on this point). Even if the budget deficits can be kept under control, the very high rates of payroll taxation used to finance the social spending are likely to impose significant economic costs on the region, as has been alleged to be the case in the welfare states of Eastern Europe.

Before leaving our discussion of the political economy of reform in East Asia and the EEFSU, it is worthwhile to focus on one theme not yet discussed: the role of the rule of law in economic reform. Even if China and Russia can manage the problems of budgetary control, market liberalization, and state sector reform, they must complete a task of historical challenge: to introduce a robust legal system as an underpinning of the market economy. At China's relatively low level of economic development, with twothirds of the labor force still in the peasant sector, the rule of law has not yet been a major constraint on economic growth. But for the more complex economies of the EEFSU today, and for China in the future at a higher level of economic development, the rule of law will be absolutely vital if markets are to be effective in replacing administrative fiat as the foundation of the division of 
labor in the economy, and if the state itself is going to be able to function in a stable manner.

In some of the countries of Eastern Europe, the transition to commercial law has been relatively smooth. Czechoslovakia, Poland, and Hungary have interwar traditions of commercial law that they can draw upon." Even before World war I, Czechoslovakia, Hungary and part of Poland were part of the Austro-Hungarian empire, which had a legal system based on Roman Law common to continental Europe. And even earlier, Poland demonstrated its rule-of-law tradition in promulgating Europe's first written constitution, in 1791.

Russia, by contrast, has no interwar tradition to draw upon, and pre-revolution Russian was also deeply deficient in its legal framework. The patrimonial tradition in Russia put all of Russian property nominally under the ownership and control of the Tsar. There was no legal or moral concept of private property rights. In practice, feudal boyars were sovereign in their own estates, so that the serfs of Russia had no protection of civil or property rights and had not recourse to the state itself. Some legal reforms had taken place during the reign of Alexander II, but these were checked by his autocratic and reactionary son, Alexander III. During the entire tsarist period, for example, Russia never adopted a modern company law, despite nearly three-quarters century of 
debate over the need for a modern company code. (See Owen, 1991, for a brilliant history of the debate over the tsarist company law).

The absence of the rule of law in Russia today is painfully evident in all aspects of its current struggles over reform. Privatization is being hampered by the absence of securities law. Financial scams are rampant. Tax evasion is widespread and rising. Even straightforward contracts are nearly impossible to enforce, since the judicial and police system do not function to protect private property rights. There is an increased reliance on "private" mafias for hire as agents of contract enforcement, a phenomenon strongly reminiscent of the private enforcement system that gave birth to the Sicilian mafia in Southern Italy (see Gambetta, 1993, for an analytical and historical account of the Sicilian mafia, and Leitzel, et. al., 1994, for an application to Russia). With the sharp rise in criminality and private "mafia" enforcement of economic relations, the state itself is at risk, if only because of its declining capacity to provide basic security to its citizens, and to collect tax revenues to cover these basic services.

China's historical tradition regarding the rule of law is not more helpful. The Confucian tradition long put property relations 
at the mercy of local aristocrat-bureaucrats, who could ruthlessly "squeeze" the local merchants and peasants for increased tax payments and bribes. There was no recourse to the law for protection of property rights. As Fairbank (1992, 180-81) summarizes a generation of research:

In short, capitalism failed to prosper in China because the merchant was never able to become established outside the control of the landlord gentry and their representatives in the bureaucracy. In feudal Europe the merchant class developed in the towns. Since the landed ruling class were settled in their manors upon the land, the European towns could grow up outside the feudal system instead of being integrated in it. Medieval burghers gained their independence by having a separate habitat in these new towns, and new political authority to protect them, in the persons of the kings of nation-states. In China, these conditions were lacking. The early abolition of feudalism and the dependence of the emperor and his officials upon the local gentry left no political power outside the established order to which the merchant could turn for special protection. . . Between them, the gentry and officials saw to it that the merchants remained under control and contributed to their coffers instead of setting up a separate economy.

In China, the absence of a system of commercial law has not yet severely hampered the reforms mainly because of China's early stage of economic development. This is evident, for example, in the role of foreign investors in China's economy. Foreign investors have shown themselves willing to invest tens of billions of dollars into China, despite the absence of a clear legal system of property rights. ${ }^{5}$ But this has been possible because the 
foreign investors operate on the "edge" of the economy, both literally and figuratively. These enterprises operate in coastal and border regions; import the components they need for assembly; use low-cost labor for the assembly operations; and then export the finished product for the world market. There is relatively little integration with domestic Chinese firms, either for the purchase of inputs or the sale of outputs. In other words, these firms have been able to function without much legal protection since, they have few contractual relations with Chinese enterprises.

The absence of rule of law has recently started to adversely affect China's international economic relations. Towards the end of 1994, the Chinese government became embroiled in several contractual disputes with foreign companies. Some Chinese enterprises defaulted on debts to foreign investment banks. The Chinese Government defaulted on a long-term lease with the large McDonald's outlet in Beijing, which it has forced to move from its premises in order to make room for a new real estate development. The Chinese Government became more deeply enmeshed in controversy with the United States Government over China's failure to protect intellectual property rights. Within China, moreover, growing lawlessness and corruption are also threatening political stability. As one acute analyst (Willy Wo-Lap Lam, 1995, p. 411) 
has written: "[The attractiveness of the 'socialist market-economy' may be ephemeral. Within a few year, it enabled senior officials and their offspring to make a fast buck. At least superficially, it also allowed the CCP to maintain its monopoly on power. Yet in the longer run, this contraption might prove detrimental to the interests of all."

\section{V}

Both EEFSU and East Asian economies in transition reveal complex patterns of adjustment, that can not be reduced to simple debates over "shock therapy" in EEFSU versus East Asian gradualism. These economies start from very different levels of development with very different roles of the state. What has worked in East Asia does not automatically work in Eastern Europe or Russia, and vice versa. More to the point, the attempt of soviet reformers in the 1980 s to institute Chinese-style reforms failed badly.

In the EEFSU, the countries that succeeded in implementing rapid and comprehensive reforms have done the best. The gradual reformers have done poorly. Fears of large declines in living standards as a result of "shock therapy" in Poland and elsewhere in Eastern Europe have not been borne out. Several countries seem to be securely on the path of democratization and reintegration in 
Western Europe. Perhaps the greatest economic challenge in the medium term will be to reduce the scope and ambition of the social welfare state, both to ease chronic fiscal pressures, and to reduce the distortions caused by very high levels of labor taxation. Russia has proven to be a particularly difficult case, as yet unable to sustain a coherent economic policy or to implement necessary measures for financial stabilization. Partly as a result of this incoherence, and partly as the result of the lack of a tradition of rule of law, Russian society and the Russian state are victims of massive corruption and criminality, and the resort to mafia-style violence to enforce private agreements.

In China and Vietnam, the early reform successes have been easier to achieve, because of the lower level of development, the reduced expectations concerning the role of the state, and the existence of an ample supply of low-cost labor outside of the state sector, which has fueled the growth of dynamic non-state sectors. Yet in China, there are also serious clouds over the medium term. As in Russia, the rule of law is weak or non-existent. The political system is subject to unpredictable developments. And even the limited state sector is imposing heavy fiscal costs that could still ignite an explosive inflation in the future. Therefore, it is likely that China and other transition countries 
in East Asia will have to turn to the more "orthodox" aspects of reforms that they have so far avoided: privatization, stateenterprise restructuring and bankruptcy, the promotion of commercial law. 


\section{LIST OF REFERENCES}

Balcerowicz, L. and A. Gelb (1994), "Macropolicies in Transition to a Market Economy: A Three-Year Perspective," Proceedings of the World Bank Annual Conference on Development Economics 1994, Washington: The World Bank, pp. 21-56.

Berliner, J. (1993). "Perestroika and the Chinese Model," mimeo, Brandeis University.

Berg, A. and J. Sachs (1994). "Structural Adjustment and International Trade in Eastern Europe: the Case of Poland," Economic Policy, 14: 117-173

Cook, Linda J. (1993). The Soviet Social contract and Why It Failed. Cambridge: Harvard University Press

Dapice, D., J Haughton, and D. H. Perkins, eds. (1994). In Search of the Dragon's Trail: Economic Reform in Vietnam, Cambridge: Harvard Institute for International Development

Eichengreen, B. and M. Uzan (1992). "The Marshall Plan: Economic Effects and Implications for Eastern Europe and the Former USSR," Economic Policy

European Bank for Reconstruction and Development (1994), Transition Report, 1994, London

Emi, K. (1963). Government Fiscal Activity and Economic Growth in Japan, 1868-1960, Economic Research Series No. 6, Institute of Economic Research, Hitotsubashi University, Tokyo: Kenkyusha Printing Co.

Emi, K. (1978). Essays on the Service Industry and Social security in Japan, Economic Research Series No. 17, Institute of Economic Research, Hitotubashi University, Tokyo: Kenkyusha Printing Co.

Fairbank, J. (1992), China: A New History, Cambridge, MA: Harvard University Press.

Fernandez, R. and D. Rodrik (1991), "Resistance to Reform: Status Quo Bias in the Presence of Individual-Specific Uncertainty," American Economic Review, December, pp. 1146-1155 
Fukao, M., M. Oumi, K. Etoh (1993), "Japan's Experience in the Immediate Postwar Period: Moving Toward a Single Exchange Rate and Denationalization of Trade," in J. Teranishi and Y. Kosai (eds.), The Japanese Experience of Economic Reforms, New York: St. Martin's Press, 1993, pp. 105-128.

Gambetta, D. (1993). The Sicilian Mafia. Cambridge: Harvard University Press

Gang Yi (1994). Money, Banking and Financial Markets in China. Boulder: Westview Press (forthcoming)

Johnson, S. and G. Loveman (1995). Starting Over in Eastern Europe, Cambridge: Harvard Business School Press

Lam, Willy Wo-Lap (1995). China after Deng Xiaoping. Hong Kong: P.A. Professional Consultants Ltd.

Leitzel, J., C. Gaddy, and M. Alexeev (1994). "Mafiosi and Matrioshki," Brookings Review, Winter 1995, pp. 26-29

Lindauer, D. (1994). "Economic Growth and the Labor Market," in Dapice, Haughton, and Perkins (1994).

Okita, S. (1980). The Developing Countries and Japan, Tokyo: University of Tokyo Press

Owen, T.C. (1991). Corporation under Russian Law, 1800-1917, Cambridge, New York: Cambridge University Press.

Qian, Y. And C. Xu (1993), "Why China's Economic Reforms Differ: The M-Form Hierarchy and Entry/Expansion of the Non-State Sector," presented at the Conference on Transition of Centrally Planned Economies in Pacific Asia, Asia Foundation, San Francisco.

Riedel, J. and B. Comer (1995). "Transition to the Market Economy in Vietnam," prepared for the Asia Foundation Project on Economic in Transition: Comparing Asia and Eastern Europe, Johns Hopkins University, March

Rodrik, D. (1995). "Getting Interventions Right," Economic Policy, April 

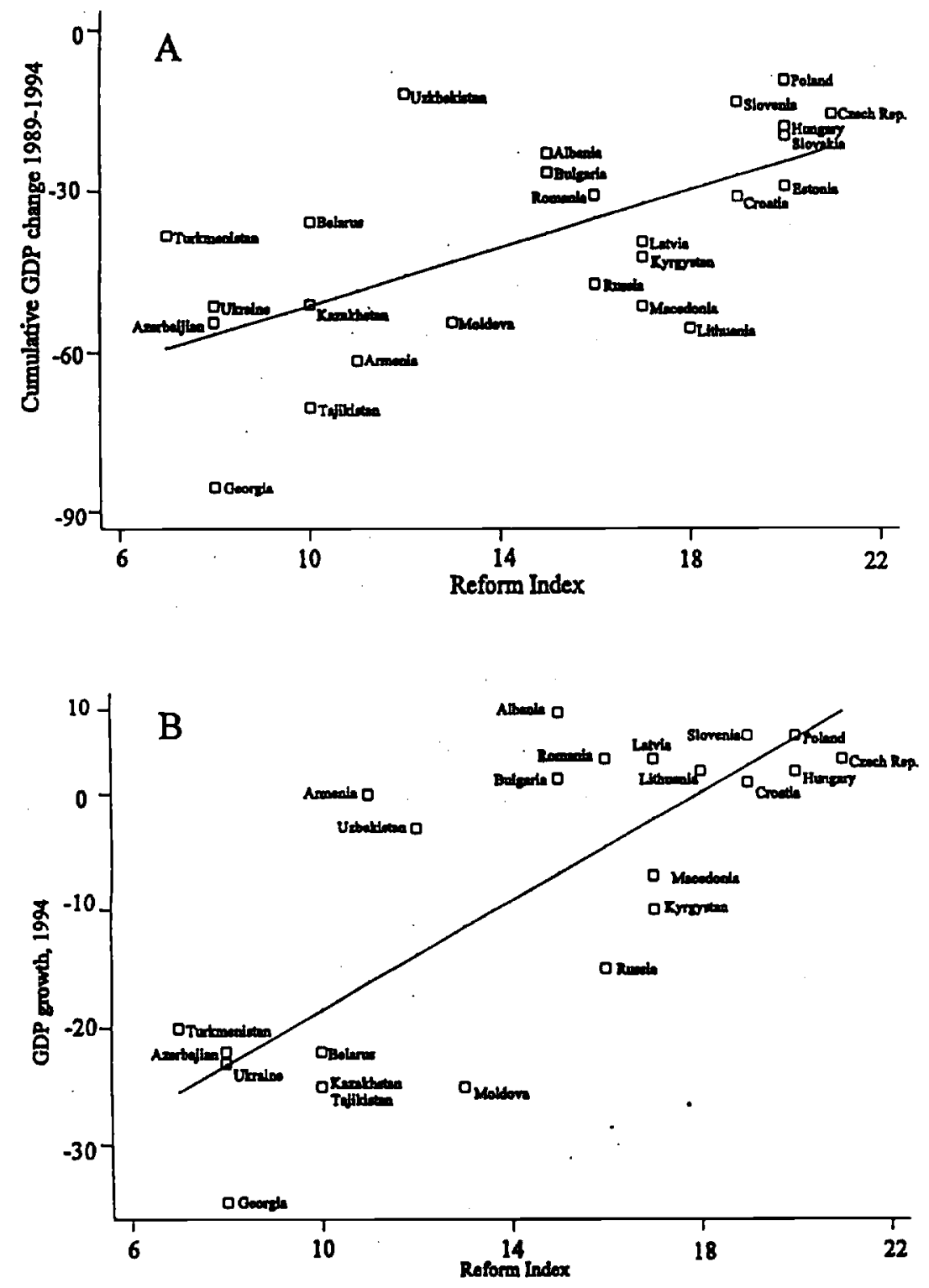

Fig. 1. The relationship of economic reforms and economic growth in Eastern Europe and the former Soviet Union: (A) cumulative GDP change 1989-1994, and (B) GDP growth, 1994. 
Table 1. Economies in Transition, GDP growth per year

\begin{tabular}{||l|l|l|l|l|l|l||}
\hline Country & $1986-89$ & 1990 & 1991 & 1992 & 1993 & $1994^{\mathrm{p}}$ \\
\hline East Asia & & & & & & \\
\hline China & 8.7 & 4.1 & 7.7 & 12.8 & 13.4 & 11.8 \\
\hline Vietnam & 5.7 & 5.1 & 6.0 & 8.6 & 8.1 & 8.8 \\
\hline EEFSU & & & & & & \\
\hline Bulgaria & 5.2 & -9.0 & -11.7 & -5.6 & -4.2 & 1.4 \\
\hline Czech Rep & 1.6 & -0.4 & -14.2 & -7.1 & -0.3 & 3.0 \\
\hline Hungary & 1.4 & -3.5 & -11.9 & -4.3 & -2.3 & 2.0 \\
\hline Poland & 2.7 & -11.6 & -7.6 & 1.5 & 3.8 & 5.0 \\
\hline Romania & -0.9 & -5.6 & -12.9 & -13.6 & 1.0 & 3.0 \\
\hline Russia & 2.4 & -2.0 & -9.0 & -19.0 & -12.0 & -15.0 \\
\hline
\end{tabular}

Ppreliminary.

Sources: 1986-89, Sachs and Woo (1994). 1990-94 for EEFSU, EBRD (1994). China, Sachs and woo (1994), United Nations, The World Economy at the Start of 1995 (December 1994), and Pacific Economic Cooperation Council, Pacific Economic Outlook 1995-1996. Vietnam, from Dapice, Haughton and Perkins (eds.), In search of the Dragon's Tail: Economic Reform in Vietnam, Harvard Institute for International Development, December 1994, for 1986-93, and Pacific Economic Cooperation Council, Pacific Economic Outlook 1995-1996, for 1994 . 
Table 2. Indicators of Economic Development

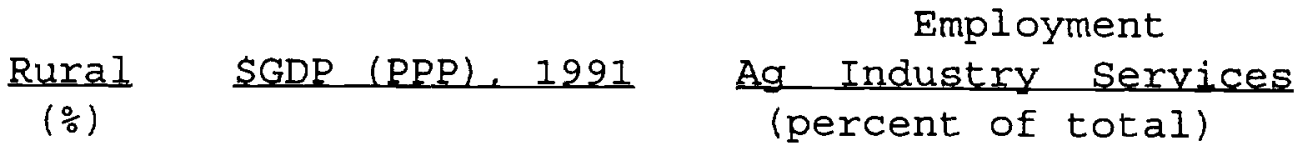

East Asian transition economies

$\begin{array}{lccccc}\text { China } & 72 & 2946 & 73 & 14 & 13 \\ \text { Vietnam } & 80 & 1250 & 67 & 12 & 21 \\ \text { Laos } & 80 & 1760 & 76 & 7 & 17 \\ \text { Eastern Europe and the Former Soviet Union } & & & \\ \text { Poland } & 37 & 4500 & 27 & 37 & 36 \\ \text { Hungary } & 34 & 6080 & 15 & 31 & 54 \\ \text { Bulgaria } & 31 & 4813 & 17 & 38 & 45 \\ \text { Russia } & 26 & 6930 & 20 & 46 & 34\end{array}$

East Asian NICs

Thailand

$72 \quad 5270$

67

11

22

Malaysia

55

7400

26

28

46

Indonesia

$70 \quad 2730$

56

14

30

Latin American NICs

$\begin{array}{lccccc}\text { Argentina } & 13 & 5120 & 13 & 34 & 53 \\ \text { Brazil } & 23 & 5240 & 25 & 25 & 47 \\ \text { Mexico } & 26 & 7170 & 23 & 29 & 48 \\ \text { Chile } & 15 & 7060 & 19 & 26 & 55\end{array}$


Source: United Nations Development Programme, Human Development Report 1994, for all data except Japan (1950). Rural population from Paul Bairoch, Cities and Economic Development, University of Chicago, 1988, Table 19.1, p. 302. 
Table 3. Distribution of Employment by type of Organization (in percent)

\begin{tabular}{lccccc} 
& \multicolumn{3}{c}{ China } & \multicolumn{2}{c}{ Russia } \\
\cline { 2 - 6 } & 1978 & 1984 & 1991 & 1985 & 1991 \\
& & & & & \\
State enterprise & 18.6 & 17.9 & 18.3 & 93.1 & 86.1 \\
$\begin{array}{l}\text { Collective Agri- } \\
\text { Culture }\end{array}$ & 72.0 & 67.0 & 63.9 & 6.0 & 5.3 \\
$\begin{array}{l}\text { Urban collective } \\
\text { Industrial TVEs }\end{array}$ & 5.1 & 6.7 & 6.2 & na & na \\
Private and other & 0.0 & 7.6 & 10.0 & na & na
\end{tabular}

Notes: For China, all agricultural activities and non-industrial TVEs are put in the "collective agriculture" category. Source is China statistical Yearbook 1992.

For Russia, state enterprises included leased state enterprises as well as traditional (pre-1985) consumer cooperatives (mainly in retail distribution). Post-1985 cooperatives are counted in "private and other." For Russia, collective agriculture is kolkhoz employment. As discribed in the text, the organization of the kolkhoz sector is virtually indistinguishable from the state-farm sector (sokhoz).

Source: Sachs and Woo, 1994, Table 4, p. 108. 
Table 4. Economic Reforms and GDP Growth in the EEFSU

\begin{tabular}{|c|c|c|c|}
\hline Reform group & $\begin{array}{l}\text { Rating } \\
(4-24)\end{array}$ & $\begin{array}{l}\text { Cumulative GDP } \\
(1989-94)\end{array}$ & $\begin{array}{l}\text { GDP Growth } \\
(1994)\end{array}$ \\
\hline \multicolumn{4}{|l|}{$\begin{array}{l}\text { Strong reform } \\
(20-24)\end{array}$} \\
\hline Czech Republic & 21 & -15.49 & 3 \\
\hline Estonia & 20 & -29.15 & 5 \\
\hline Hungary & 20 & -17.94 & 2 \\
\hline Poland & 20 & -9.23 & 5 \\
\hline Slovakia & 20 & -19.53 & 5 \\
\hline Averages & 20.4 & -18.27 & 4 \\
\hline \multicolumn{4}{|l|}{$\begin{array}{l}\text { Moderate } \\
\text { Reform }(15-19)\end{array}$} \\
\hline Croatia & 19 & -31.04 & 1 \\
\hline slovenia & 19 & -13.26 & 5 \\
\hline Lithuania & 18 & -55.44 & 2 \\
\hline Macedonia & 17 & -51.30 & -7 \\
\hline Kyrgyzstan & 17 & -42.30 & -10 \\
\hline Latvia & 17 & -39.52 & 3 \\
\hline Romania & 16 & -30.79 & 3 \\
\hline Russia & 16 & -47.29 & -15 \\
\hline Bulgaria & 15 & -26.41 & 1.4 \\
\hline Albania & 15 & -22.89 & 7 \\
\hline Averages & 16.9 & -36.02 & -1 \\
\hline \multicolumn{4}{|l|}{$\begin{array}{l}\text { Weak Reform } \\
(4-14)\end{array}$} \\
\hline Moldova & 13 & -54.30 & -25 \\
\hline Uzbekistan & 12 & -11.75 & -3 \\
\hline
\end{tabular}




\begin{tabular}{||l|l|l|l||}
\hline Armenia & 11 & -61.60 & 0 \\
\hline Belarus & 10 & -35.93 & -22 \\
\hline Kazakhstan & 10 & -51.01 & -25 \\
\hline Tajikistan & 10 & -70.37 & -25 \\
\hline Azerbaijan & 8 & -54.32 & -22 \\
\hline Ukraine & 8 & -51.36 & -23 \\
\hline Georgia & 8 & -85.35 & -35 \\
\hline Turkmenistan & 7 & -38.29 & -35 \\
\hline Averages & 9.7 & -51.43 & -21 \\
\hline
\end{tabular}

Source: Reform rankings from the EBRD, 1994, Table 2.1, p. 10. The six indexes of reform strength are summed to produce an overall 16, p. 62 . 
Table 5 .

Social Expenditures

(percent of GDP)

GDP per Capita Social Educ. Health Total

\section{Developing Countries}

South Asia

East Asia

Latin America

Eastern Europe

OECD
1260

3210

5360

5210

19000
0.7

3.4

1.4

5.5

3.4

2.8

2.2

8.4

3.4

4.2

2.4

10.0

14.9

4.8

5.2

24.9

Source: United Nations Development Programme, Human Development Repert 1994, New York: Oxford University Press
$4.9 \quad 5.9$

27.1 
Table 6. Public Pension Spending, Various Countries

\begin{tabular}{|c|c|}
\hline Country & Public pension spending/GDP \\
\hline \multicolumn{2}{|l|}{ EEFSU } \\
\hline Albania & 7.9 \\
\hline Bulgaria & 7.9 \\
\hline Czech Republic & 8.2 \\
\hline Hungary & 9.7 \\
\hline Poland & 12.4 \\
\hline Russia & 7.1 \\
\hline $\begin{array}{l}\text { EEFSU Average (some countries } \\
\text { not shown) }\end{array}$ & 8.0 \\
\hline \multicolumn{2}{|l|}{ OECD } \\
\hline France & 11.8 \\
\hline Germany & 10.8 \\
\hline Italy & 14.4 \\
\hline Japan & 5.0 \\
\hline Spain & 7.5 \\
\hline United States & 6.5 \\
\hline $\begin{array}{l}\text { OECD average (some countries } \\
\text { not shown) }\end{array}$ & 9.2 \\
\hline \multicolumn{2}{|l|}{ Asia } \\
\hline China & 2.6 \\
\hline India & 0.6 \\
\hline Indonesia & 0.1 \\
\hline Malaysia & 1.6 \\
\hline $\begin{array}{l}\text { Asia average (some countries } \\
\text { not shown) }\end{array}$ & 1.9 \\
\hline
\end{tabular}


Source: World Bank, Averting the old Age Crisis, Oxford: Oxford University Press, 1994 
Table 7 .

Japan Social Expenditures, 1947-1955

(billion Yen)

$\begin{array}{ccc}\text { Pensions Transfers GDP } & \begin{array}{c}\text { Pensions } \\ (\% G D P)\end{array} & \text { Transfers } \\ & & \end{array}$

$\begin{array}{rrrrrr}1946-50 & 10^{\mathrm{a}} & 259 & 11771 & 0.1^{\mathrm{a}} & 2.2 \\ 1951-55 & 237 & 1314 & 34349 & 0.7 & 3.8\end{array}$

a1947-50

Social expenditure is the sum of Series 2 and 5, Table 2, pp. 71, K. Emi (1978). GNP is Series 1, Table 3, p. 74, K. Emi (1978)

Note: Transfers are the sum of social expenditures of the central and local governments, including pensions. 
Table 8 .

\begin{tabular}{|c|c|c|c|c|}
\hline & \multicolumn{2}{|c|}{ Social Expenditures } & \multicolumn{2}{|c|}{ Subsidies } \\
\hline & $\begin{array}{l}\text { Pre-reform } \\
\quad(1989)\end{array}$ & $\begin{array}{c}\text { Post-reform } \\
(1993)\end{array}$ & $\begin{array}{c}\text { Pre-reform } \\
(1989)\end{array}$ & $\begin{array}{c}\text { Post-reform } \\
(1993)\end{array}$ \\
\hline Poland & 10.0 & 21.0 & 12.9 & 3.3 \\
\hline Hungary & 15.8 & 22.5 & 10.7 & 3.1 \\
\hline Bulgaria & 10.4 & 12.9 & 15.5 & 3.9 \\
\hline Czech Republic & 13.2 & 14.6 & 16.6 & na \\
\hline Russia & 14.8 & 13.1 & 8.5 & 12.0 \\
\hline
\end{tabular}

Source: European Bank for Reconstruction and Development, Transition Report, 1994, Table 6.6, p. 87 except for Poland, which is based on national data. 


\section{NOTES}

1. This paper draws heavily on Sachs and Woo (1994), as well as on ongoing research with Professor woo on international comparisons of social welfare spending in Europe, Latin America, and Asia.

2. The following dollar figures for Japanese GDP for 1946-52 are used in the calculation in the text (all in \$ billion): 6.25, $7.66,9.26,9.38,10.96,15.12,16.99$. There are taken from Fukao, et. al. (1993), Table 5.6, p. 119. The aid data are taken from U.S. Overseas Loans and Grants, July 1, 1945 - September 30, 1993, U.S. Agency for International Development.

3. I have estimated the necessary budgetary support for Russia at around $\$ 15$ billion per year from the west. As the OECD GDP is on the order of $\$ 20$ trillion, the Russian aid would amount to 0.075 percent of GDP, that is, less than one-tenth of one percent. Moreover, some of this aid could have come in the form of loans rather than grants.

4. For example, at the start of Poland's market reforms in 1989, the 1934 Commercial Code was brought back into operation.

5. Note that much of the apparent foreign investment, however, is actually laundered Chinese state-enterprise funds, which have been illegally taken out of China to Hong Kong, and then recycled as private funds back into China. Hong Kong analysts put the laundered funds as equal to half of more of the recorded foreign investment from Hong Kong to China. The Hong Kong investment, in turn, is more than half of the total FDI now entering china according to the official statistics. 